УДК 620.92

\title{
АНАЛІЗ МОЖЛИВОСТІ ОТРИМАННЯ ДЕРЕВНОГО ПАЛИВА 3 ДОДАТКОВИХ ДЖЕРЕЛ В УКРАЇНІ
}

\begin{abstract}
Проаналізовано темпи розвитку біоенергетики в Україні. Розглянуто можливості отримання деревного біопалива 3 додаткових джерел, таких як полезахисні лісові смуги, лісові насадження вздовж автомобільних доріг та залізниць, а також сухостій. Показано, що за рахунок вказаних додаткових джерел можна збільшити енергетичний потенціал деревної біомаси в Україні у більше ніж 2 рази.

Проанализированы темпы развития биоэнергетики в Украине. Рассмотрены возможности получения древесного биотоплива из дополнительных источников, таких как полезащитные лесополосы, лесные насаждения вдоль автомобильных и железных дорог, а также сухостой. Показано, что за счет указанных дополнительных источников можно увеличить энергетический потенциал древесной биомассы в Украине в более чем 2 раза.
\end{abstract}

Желсзна T.А., канд. тех. наук, Баштовий А.І., канд. тех. наук, Гелетуха Г.Г., канд. тех. наук Інститут технічної теплофізики НАН України, вул. Желябова, 2а, Київ, 03680, Україна

Бібл. 7, табл. 1, рис. 3.
Rate of development of bioenergy in Ukraine is analyzed. The paper considers possibilities for obtaining wood fuel from such additional sources as shelterbelt forests, shelter forests along motor roads and railways and dead wood. It is shown that the use of these additional sources may increase the energy potential of wood biomass in Ukraine in more than two times.

Ключові слова: біомаса, біопаливо, деревна біомаса, деревне паливо, полезахисні лісосмуги, сухостій, енергетичний потенціал.

ЛС - лісосмуга;

НПДВЕ - Національний план дій з відновлюваної енергетики;

ПГ - природний газ;

\section{Тенденції розвитку біоенергетики в Украӥні}

Аналіз даних Енергетичного балансу України за 2010...2014 pр. показує значне зростання обсягів виробництва та використання біопалив у середньому на $42 \%$ на рік [1]. При такому ж тренді розвитку біоенергетики, у 2020 р. біопаливами буде заміщатися 5,38 млрд. $\mathrm{M}^{3} /$ рік природного газу (рис. 1). Цілі Національного плану дій з відновлюваної енергетики на період до 2020 року [2], перераховані у обсяги заміщення природного газу (сума об'ємів заміщення ПГ при виробництві теплової енергії у котельних та при сумісному виробництві ТЕ 3 електроенергією в режимі ТЕЦ), свідчать про те, що у 2020 році передбачено заміщення 7,2 млрд. м $^{3}$ рік природного газу за рахунок біомаси.

Хоча біоенергетика в Україні розвивається досить динамічно, очевидно, що цих темпів все ж недостатньо для досягнення цілей НПДВЕ по
ПЗЛС - полезахисні лісові смуги;

ТЕ - теплова енергія;

ТЕЦ - теплоелектроцентраль;

у.П. - умовне паливо.

біомасі на 2020 р. Підвищення темпів розвитку біоенергетики означає збільшення обсягів використання біомаси для потреб енергетики. В першу чергу, це мають бути відходи сільського господарства та енергетичні культури. Але треба зазначити, що деревна біомаса також ще має певні ресурси для збільшення свого енергетичного потенціалу.

Деревина традиційно широко застосовується в Україні для енергетичних потреб. Раніше це були, в основному, дрова, які населення використовувало в пічках, грубках та побутових котлах. Останнім часом у країні з'явилася велика кількість зарубіжного та вітчизняного сучасного обладнання для спалювання деревної тріски, гранул, брикетів. Попит на деревну біомасу як паливо збільшується, а їі технічний потенціал є доволі обмеженим - близько 2 млн. т у.п./рік (відходи рубок та деревообробки, дрова для опалення) $\mathrm{i}$ вже майже повністю утилізується. 


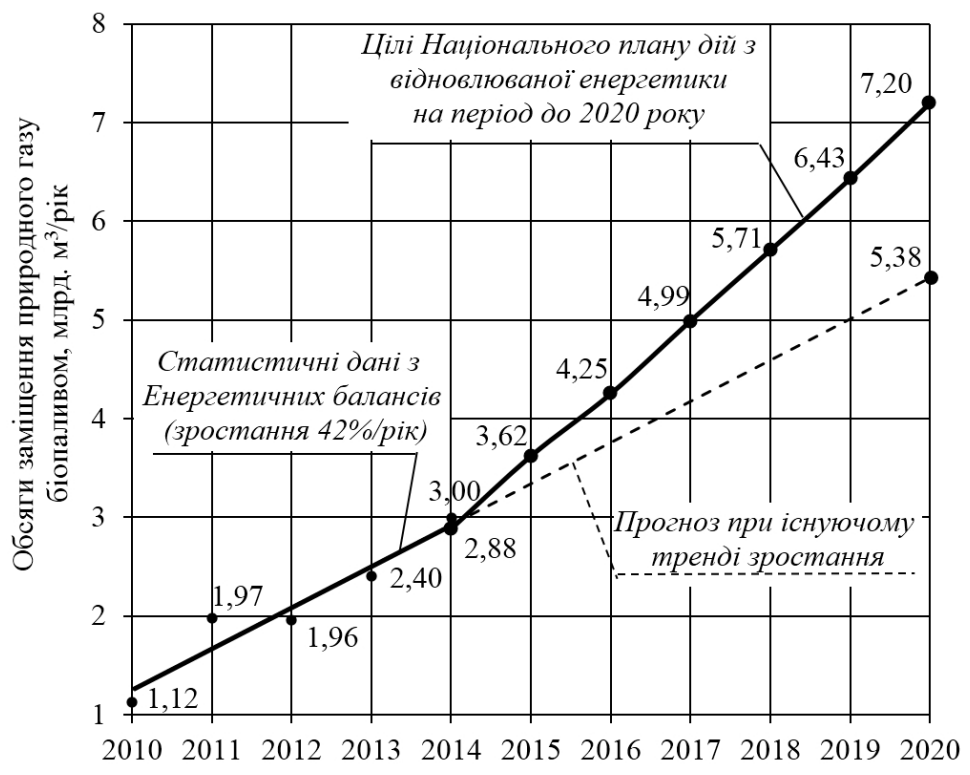

Рис. 1. Тенденції розвитку біоенергетики в Украӥні.

Обсяги заготівлі ліквідної деревини (a, у Державному агентстві лісових ресурсів та відповідно, і обсяги відходів лісозаготівлі), у Міністерстві екології та природних ресурсів, що тому числі дров, можна назвати скоріше стабільними, ніж постійно зростаючими в Україні (рис. 2). Усі держлісгоспи мають так звану «розрахункову лісосіку», затверджену на роки вперед. Для іiі збільшення необхідно отримати дозвіл $\epsilon$ практично нереальним. Тому актуальним є пошук і аналіз додаткових джерел деревного палива, серед яких можуть бути полезахисні лісосмуги, лісонасадження уздовж автомобільних доріг i залізниць, а також сухостій.

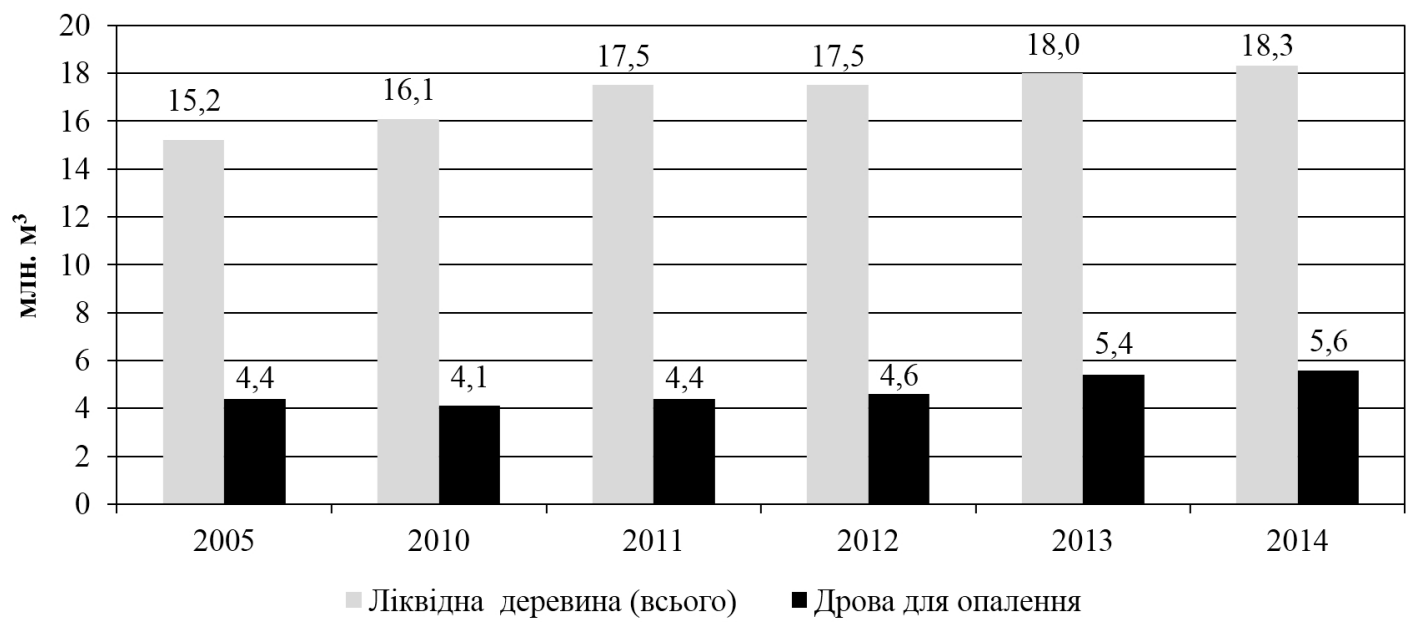

Рис. 2. Заготівля ліквідної деревини в Украӥні [3].

\section{Полезахисні лісові смуги}

Полезахисні лісові смуги - це штучні насадження, які розмежовують масиви ріллі, виконуючи кліматорегулювальні, грунтозахисні та водоохоронні функції. Внаслідок невизначеної правової ситуації з балансоутримувачами ПЗЛС, що склалася в Україні, ці насадження протягом багатьох років не отримують належного догляду і поступово втрачають свої захисні властивості. Полезахисні лісові смуги нагально потребують реконструкції (санітарні рубки, рубки догляду) і відновлення (насадження нових плантацій). Завдяки виконанню таких робіт можна додатково отримувати до 1 млн. т у.п./рік деревного пали- 
ва. Ця оцінка грунтується на даних щодо площі ПЗЛС в Україні та можливого обсягу утворення деревних відходів при їх реконструкції.

За офіційними статистичними даними, на сьогодні в Україні налічується близько 446 тис. га полезахисних лісових смуг. Найбільші площі знаходяться у Запорізькій (51,9 тис. га), Одеській (50 тис. га) та Дніпропетровській (42,5 тис. га) областях, тоді як в Івано-Франківській, Рівненській та Чернівецькій областях ПЗЛС взагалі немає. Ряд спеціалістів вважають офіційні дані статистики неточними, посилаючись на те, що полезахисні лісові насадження зазнають незаконних рубок, а їх державний облік не здійснювався з 1976 p.

Деревина у ПЗЛС України є, переважно, низькосортною (до 90 \% і більше), тому біомасу, отриману в ході санітарних рубок та рубок догляду, можна майже повністю застосувати на потреби енергетики, не порушуючи критеріїв сталого розвитку. Згідно експертних оцінок, при виконанні робіт з реконструкції полезахисних лісосмуг можна отримувати 100...200 щільних м ${ }^{3}$ низькосортної деревини на гектар. В масштабах країни (446 тис. га ПЗЛС) це дає 30..60 млн. т, або 0,5 ...1,0 млн. т у.п./рік (у розрахунку на 20 років).

Нормативно-правовою базою, що регулює створення захисних лісових насаджень лінійного типу (до яких відносяться ПЗЛС) та проведення у них лісовпорядних робіт, є Концепція розвитку агролісомеліорації в Україні (2013р.) [4]. Реалізація Концепції передбачена протягом 2014...2025 pр. у відповідності до затвердженого Плану заходів [5]. Серед іншого, План заходів включає забезпечення лісовпорядкування захисних лісових насаджень, а також підготовку пропозицій щодо внесення відповідних змін і доповнень до законодавчих та інших нормативноправових актів. Вважаємо за необхідне на основі Концепції розробити також Державну програму, яка б, з урахуванням науково-обгрунтованих підходів, містила детальні плани щодо реконструкції та відновлення ПЗЛС та терміни їх виконання.

\section{Лісонасадження вздовжс автомобільних доріг та залізниць}

При експлуатації автомобільних доріг основ- ним джерелом впливу на атмосферне повітря $€$ транспортні засоби. Для зниження рівня забруднення повітря, серед інших природоохоронних заходів технологічного, санітарно-технічного та організаційного напрямів, застосовують лісонасадження вздовж доріг. Крім того, при експлуатації автомобільних доріг також мають місце фізичні фактори впливу на навколишнє середовище, до яких відносяться акустичний вплив та вібрація. Лісові насадження відіграють важливу роль у їх зменшенні до нормативних значень [6].

Треба зазначити, що, окрім позитивної ролі (зниження рівня забруднення повітря, зменшення рівня шуму), лісонасадження вздовж доріг у їх існуючому в Україні вигляді відіграють наразі i певну негативну роль. Якщо при виникненні аварійної ситуації автомобіль з’їжджає на узбіччя, то у разі його зіткнення зі стовбуром дерева ймовірність летального кінця для водія набагато більша, ніж при зіткненні 3 чагарником. Тому у світовій практиці все частіше вважається за доцільне поступово замінити лісосмуги вздовж автомобільних доріг на чагарникові насадження. Деревна біомаса, отримана в процесі цієї діяльності, може бути використана на енергетичні потреби.

Статистичні дані щодо площі захисних лісосмуг вздовж доріг відсутні, оскільки їх збір не передбачений формами Державної служби статистики України. Тому можна виконати тільки експертну оцінку, виходячи із довжини автомобільних доріг загального користування державного значення (49117,4 км) та можливої ширини лісосмуг (10 м). Приймаючи, що реконструкція лісосмуг буде виконуватися на чверті довжини цих доріг протягом 10 років, обсяг отриманого деревного палива становитиме близько 1,5 млн. т або 51,4 тис. т у.п./рік.

Згідно Державних будівельних норм [7], захисні лісові насадження вздовж залізниць використовуються для їх захисту від снігових, піщаних та земляних заметів, шкідливого впливу інших несприятливих природних явищ, а також для захисту від шуму при проходженні потягів та від пилу при масових перевезеннях сипучих вантажів. Слід зазначити, що при виборі технічних заходів для такого захисту залізниці перевага 
надається створенню захисних лісонасаджень.

Оскільки статистичні дані щодо площі захисних лісонасаджень вздовж залізниць також відсутні, виконаємо експертну оцінку, грунтуючись на довжині залізничних колій загального користування (20948,1 км), можливій ширині лісосмуг (15 м) та таких же припущень, що були прийняті відносно лісосмуг вздовж автомобільних доріг. Тоді обсяг деревного палива, отриманого від реконструкції захисних лісонасаджень вздовж залізниць України складатиме близько 0,96 млн. т або 32,7 тис. т у.п./рік.

\section{Сухостій}

Сухостій - це засохлі дерева і кущі, які стоять на корені. Причина утворення сухостою різкі кліматичні коливання температури, вологи, «нижня пожежа» (вигорання сухої трави, при якому дерева ще не займаються, але суттєво пошкоджуються), термічне, хімічне, механічне чи інше суттєве пошкодження кореневищ, кори чи листяного покриву дерев, а також їх старіння, всихання. Фахівці лісового господарства не заперечують, що сухостій зі звичайних лісів майже повністю може бути утилізований для потреб енергетики. Але обов'язково треба залишати на місті кілька великих дерев на гектар для збереження біорозмаїття.

Сухостій існує практично у всіх лісах і разом з іншими видами деревного відпаду відіграє важливу роль у процесі кругообігу органічної речовини. За нормальних умов обсяг сухостою становить до $10 \ldots 11 \mathrm{~m}^{3} /$ га. Окремим небезпечним для екології випадком є масове висихання дерев, коли запас сухостою на гектар збільшується на порядок. Таким прикладом є масштабне висихання смерек в Українських Карпатах на площі 30...35 тис. га (Івано-Франківська та Львівська області).

Спеціалісти лісового господарства вважають, що існуюча система обліку лісів не забезпечує достовірної інформації про запаси та динаміку кількості мертвої деревини (у т.ч. сухостою) у лісах України. Використовуючи певний методичний підхід, фахівці Національного університету біоресурсів і природокористування оцінили запас сухостою в Україні у 92,6 млн. м ${ }^{3}$ (зі середньоквадратичною похибкою $10 \ldots 15 \%$ ) [8]. Якщо припустити, що лише половина загального потенціалу сухостою $\epsilon$ технічно досяжною та економічно доцільною для утилізації протягом 10 років, то цей обсяг складатиме 32,4 млн. т або 1,44 млн. т у.п./рік.

Таким чином, підсумовуючи зазначене вище, загальний об'єм деревного палива 3 додаткових джерел в Україні можна оцінити у 2,5 млн. т у.п./рік (табл. 1). Цей обсяг є дуже вагомим, оскільки він збільшує існуючий енергетичний потенціал деревини (2 млн. т у.п./рік з традиційних джерел) у 2,3 рази до 4,5 млн. т у.П./рік (рис. 3). При цьому найбільші частки потенціалу припадають на сухостій (32\%), дрова (29 \%) та деревину з ПЗЛС $(21 \%)$.

Для реалізації проектів 3 реконструкції та відновлення ПЗЛС, отримання деревного палива шляхом впорядкування інших захисних насаджень, а також заготівлі сухостою необхідна

Таблица. Энергетический баланс Земли (тепловые потоки, ТВт)

\begin{tabular}{|l|c|c|c|c|}
\hline \multirow{2}{*}{ Джерело деревного палива } & \multirow{2}{*}{$\begin{array}{c}\text { Загальний } \\
\text { ресурс, млн. }\end{array}$} & \multirow{2}{*}{$\begin{array}{c}\text { Кількість років } \\
\text { використання }\end{array}$} & $\begin{array}{c}\text { Річний потенціал деревного палива } \\
\text { (орехнічний, економічний) }\end{array}$ \\
\cline { 4 - 5 } & & 20 & 2730 & тис. т у.п./piк $^{2}$ \\
\hline Полезахисні лісосмуги & 54,6 & 10 & 150 & $532^{2}$ \\
\hline Лісосмуги вздовж автодоріг & 1,5 & 10 & 96 & 32,7 \\
\hline Лісосмуги вздовж залізниць & 0,96 & 10 & 3240 & 1440 \\
\hline Сухостій & 32,4 & & 6216 & 2456 \\
\hline Всього & 89,46 & & тис. & \\
\hline
\end{tabular}

${ }^{1}$ Для оцінки технічного/економічного потенціалу деревного палива.

${ }^{2}$ Виходячи з показника утворення деревних відходів 175 щільних м³/га. 
можливість участі приватних компаній, які будуть здатні залучити відповідні матеріальні та фінансові ресурси. Для цього потрібно зробити ряд змін та доповнень до чинного законодавства України. Ці зміни мають врегулювати ряд важливих питань, у тому числі:

- визначення власника і балансоутримувача полезахисних лісосмуг;

- надання права на проведення тендеру по виконанню робіт з реконструкції та відновлення ПЗЛС місцевим органам влади на рівні не нижче обласних державних адміністрацій;
- забезпечення можливості довгострокової оренди ПЗЛС та інших захисних лісонасаджень приватними компаніями;

- забезпечення можливості доступу приватного бізнесу до сухостою та порубкових залишків.

Детальнішу інформацію по розглянутих вище питаннях, у тому числі пропозиції щодо реалізації пілотного проекту з реконструкції та відновлення полезахисних лісосмуг в одній з областей України, представлено у роботі [9].
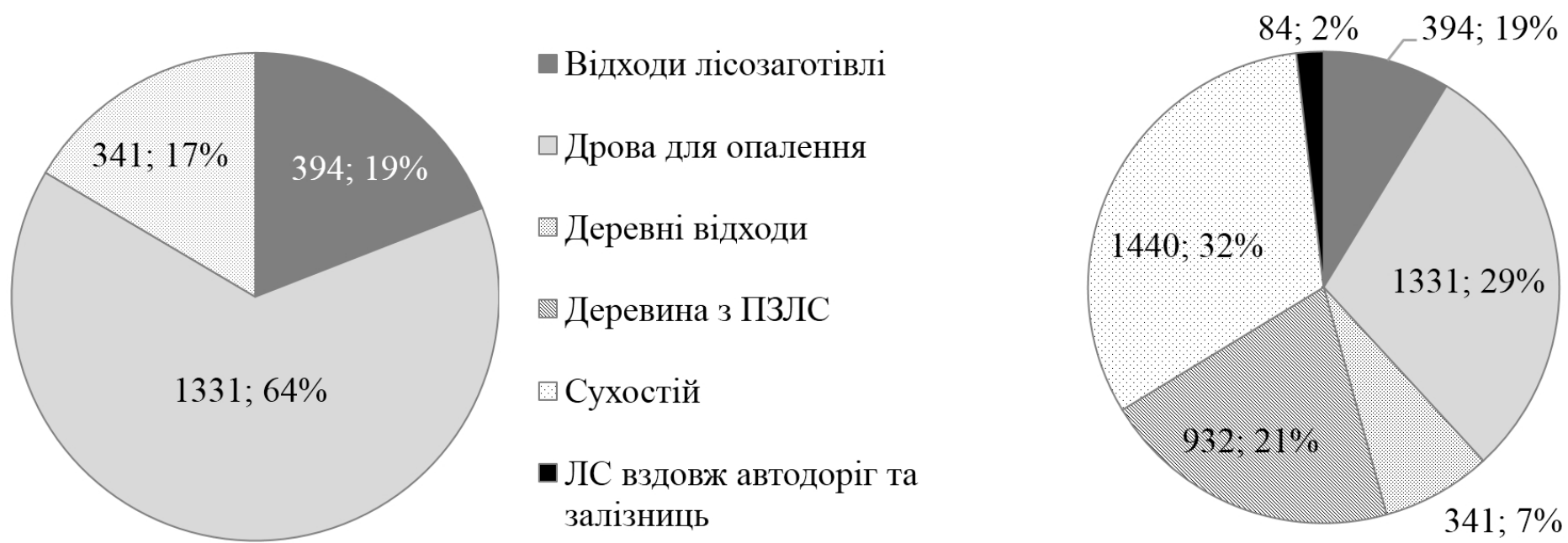

Деревна біомаса з традииійних джерел: загалом 2067 тис. m у.n./piк[3].
Деревна біомаса з традичійних та додаткових джерел: загалом 4523 тис. $m$ y.n./piк

\section{Рис. 3. Енергетичний потенціал деревної біомаси в Украӥні (2014 р.).}

\section{Висновки}

Останні кілька років темпи розвитку біоенергетики в Україні $є$ доволі високими - ріст обсягів виробництва та використання біопалив становить, в середньому, близько 42 \% на рік. Але цих темпів все ще недостатньо для досягнення цілей НПДВЕ по біомасі на 2020 рік - заміщення 7,2 млрд. м 3 /рік природного газу. Підвищення темпів розвитку біоенергетики означає збільшення обсягів використання біомаси для потреб енергетики. У першу чергу, це мають бути відходи сільського господарства та енергетичні культури. Але деревна біомаса також ще має певні ресурси для нарощування свого енергетичного потенціалу. Разом із традиційними джерелами деревного палива (відходи лісозаготівлі та деревообробки, дрова) необхідно розглядати можливості використання додаткових джерел, таких як полезахисні лісосмуги, лісонасадження уздовж автомобільних доріг і залізниць, а також сухостій. За рахунок вказаних додаткових джерел можна збільшити енергетичний потенціал деревної біомаси в Україні у більше ніж 2 рази. Для можливості практичної реалізації проектів 3 реконструкції та відновлення ПЗЛС, отримання деревного палива шляхом впорядкування інших захисних насаджень, а також заготівлі сухостою необхідне внесення ряду змін та доповнень до чинного законодавства України. 


\section{ЛІТЕРАТУРА}

1. Енергетичний баланс Украйни за 20072014 pp. Державна служба статистики України https://ukrstat.org/uk/operativ/operativ2012/energ/ en_bal/arh_2012.htm

2. Національний план дій з відновлюваної енергетики на період до 2020 року. Затверджений Розпорядженням КМУ №902-р від 01.10 .2014

3. Статистичний щзорічник України за 2014 рік. Державна служба статистики України, 2015.

4. Коничепџฺія розвитку агролісомеліорації в Україні. Схвалено Розпорядженням КМУ № 725-р від 18.09.2013.

5. Планзаходів щзодо реалізаціїКониеепіїрозвитку агролісомеліорації в Україні. Затверджено Розпорядженням КМУ № 582-р від 18.06.2014.
6. Екологічні вимоги до автомобільних доріг. Проектування. ГБН В.2.3-218-007:2912. Укравтодор, 2012.

7. Споруди транспорту. Залізниці колії 1520 мм. Норми проектування. ДБН В.2.3-192008. Мінрегіонбуд України, 2008.

8. Вуглець, клімат та землеуправління в Україні: лісовий сектор: Монографія / [А. Швиденко, П. Лакида, Д. Щепащенко, Р. Василишин, Ю. Марчук]. - Корсунь-Шевченківській: ФОП Гавришенко В.М., 2014. - 283 с.

9. Желєзна Т.А., Баштовий А.І., Гелету$x a$ Г.Г. Аналіз додаткових джерел деревного палива в Україні. Аналітична записка № 15 Біоенергетичної асоціації України, 2016. http://www.uabio.org/img/files/docs/position-paperuabio-15-ua.pdf 


\section{ANALYSIS OF POSSIBILITY TO OBTAIN WOOD FUEL FROM ADDITIONAL SOURCES IN UKRAINE}

\section{Zheliezna T.A., Bashtovyi A.I., Geletukha G.G.}

Institute of Engineering Thermophysics of the National Academy of Sciences of Ukraine, vul. Zhelyabova, 2a, Kyiv, 03680, Ukraine

Rate of development of bioenergy in Ukraine is analyzed. It is shown that in order to meet the target for biomass of the National Renewable Energy Action Plan until 2020 it is necessary to speed up bioenergy development. That means increasing volumes of biomass for energy production. The increase of biomass volumes should be realized first at the expense of agricultural residues and energy crops as their potential is much bigger than that of wood. At that wood biomass also has some resources to increase its energy potential. In additional to conventional sources of wood fuel such as felling residues, wood processing waste and fuelwood, there may be other sources like shelterbelt forests, shelter forests along motor roads and railways and dead wood. The paper considers possibilities for obtaining wood fuel from these additional sources. It is shown that the use of these sources may increase the energy potential of wood biomass in Ukraine in more than two times. Realization of projects on reconstruction of shelterbelt forests and cutting of dead wood with the involvement of private companies requires some amendments to the existing legislation of Ukraine.

References 7, tables 1, figures 3.

Key words: biomass, biofuel, wood biomass, wood fuel, shelterbelt forests, dead wood, energy potential.

1. Energy Balance of Ukraine for 2007-2014. State Statistics Service of Ukraine

https://ukrstat.org/uk/operativ/operativ2012/energ/ en_bal/arh_2012.htm

2. National Renewable Energy Action Plan until 2020. Approved by CMU Resolution № 902-p of 01.10.2014. (Ukr)

3. Statistical Yearbook of Ukraine for 2014. State Statistics Service of Ukraine, 2015.

4. Conception for the development of agricultural afforestation in Ukraine. Approved by CMU Resolution № 725-p of 18.09.2013. (Ukr)

5. Action Plan for the implementation of Conception for the development of agricultural afforestation in Ukraine. Approved by CMU Resolution № 582-p of 18.06.2014.

6. Environmental requirements to motor roads. Designing. ГБН В.2.3-218-007:2912. Ukravtodor, 2012.

7. Transport constructions. Railway tracks of 1520 mm. Designing norms. ДБН В.2.3-19-2008. Minregionbud of Ukraine, 2008.

8. Carbon, climate and land management in Ukraine: forest sector: Monograph / [A. Shvydenko, H. Lakyda, D. Schepaschenko, R. Vasylyshyn, Yu. Marchuck]. - Korsun-Shevchenkibsky: FOP Gavryshenko V.M., 2014. - 283 p. (Ukr)

9. Zheliezna T.A., Bashtovyi A.I., Geletukha G.G. Analysis of additional sources of wood fuel in Ukraine. UABio Position Paper № 15, 2016. http://www.uabio.org/img/files/docs/position-paperuabio-15-en.pdf

Получено 14.04.2016 Received 14.04.2016 